NOTICE: This is the author's version of a work that was accepted for publication in Renewable and Sustainable Energy Reviews. Changes resulting from the publishing process, such as peer review, editing, corrections, structural formatting, and other quality control mechanisms may not be reflected in this document. Changes may have been made to this work since it was submitted for publication. A definitive version was subsequently published in Renewable and Sustainable Energy Reviews, Vol. 23, (2013). doi: 10.1016/j.rser.2013.02.021 


\title{
Ocean renewable energy in Malaysia: The potential of the Straits of Malacca
}

\author{
Heap-Yih Chong ${ }^{a}$, Wei-Haur Lam ${ }^{\text {b* }}$ \\ ${ }^{a}$ Faculty Engineering and Science, Universiti Tunku Abdul Rahman, 53300 Kuala Lumpur, Malaysia \\ ${ }^{\mathrm{b}}$ Department of Civil Engineering, Faculty of Engineering, University of Malaya, 50603 Kuala Lumpur, Malaysia
}

\begin{abstract}
The need for renewable energy is a global demand due to both the economic factors and the environmental concerns. Malaysian government has been supportive on the research and development in the renewable energies. Renewable Energy Act (2011) and Sustainable Energy Development Authority Act (2011) have been enacted to boost the industry of renewable energy. This paper presents the current status and future prospects of renewable energy in Malaysia with particular focus on the ocean renewable energy. Five types of ocean renewable energy were reviewed including tidal barrage, tidal current energy, wave energy, Ocean Thermal Energy Conversion (OTEC) and salinity gradient power. The comparison of various types of ocean renewable energy has been made to present their recent technologies in electricity generation. Tidal current energy is identified as a preferable option particularly in the Straits of Malacca.
\end{abstract}

Keywords: Renewable energy, Ocean energy, tidal energy, Straits of Malacca, Malaysia

*Corresponding author. Tel.: +603 7967 7675; fax: +603 79675318.

E-mail address: wlam@um.edu.my 
Contents

1. Introduction

2. The status and prospects of renewable energies in Malaysia

2.1. Energy supply

2.2. Energy policy

2.3. The need for ocean renewable energies

3. Ocean renewable energies

3.1. Tidal barrage

3.2. Tidal current energy

3.3. Wave energy

3.4. Ocean Thermal Energy Conversion (OTEC)

3.5. Salinity gradient power

4. Challenges and comparison

5. The potential of the Straits of Malacca

6. Discussion and conclusion

Acknowledgment

References 


\section{Introduction}

The pressures from global warming and high oil price attract the worldwide concerns to prevent the serious impacts on both the economic growth [1-7] and the environmental pollution [8-14]. Population growth has significantly increased the demand for energy. The total supply of primary energy reaches 12.15 billion tons of oil equivalents to support the world population of 6.8 billion in 2009 [15]. This supply satisfied the demands from international aviation, international marine bunkers, electricity generation and heat trade. The total supply of primary energy is projected to increase $1.5 \%$ annually, which may reach the demand of 17 billion tons of oil equivalent by 2030 [16]. However, the world energy supply still heavily relies on the fossil based resources.

The consumption of fossil fuels has brought serious environmental problems especially $\mathrm{CO}_{2}$ emissions. According to International Energy Agency (IEA), nearly 68\% of the worldwide electricity was generated from the fossil fuels including coal (40.6\%), gas (21.4\%) and oil (5.1\%) in 2009. The remaining electricity was generated from hydro (16.2\%), nuclear (13.4\%) and others (3.3\%) [15]. The electricity production from the fossil fuels is higher in the developing countries. Therefore, the renewable and cleaner sources of energy are required to secure the future electricity supply for the developing countries including Malaysia.

\footnotetext{
Malaysia is promoting the renewable energy to alleviate the high dependency on fossil fuel. A number of renewable resources have been used to generate the electricity including the solar photovoltaic, biogas, biomass, mini hydro and solid waste. The utilisation of these renewable
} 
resources is able to contribute $1 \%$ of the annual electricity generation in 2011 . The contribution of renewable energy can reach 16.5 gigawatt hours (GWh) or 13\% of the total power generation by 2030 [17]. Biomass and biogas are expected to be the main contributors to the projected power generation. The previous studies of renewable energy were mainly focused on the aforementioned sources in Malaysia [18-21]. Therefore, this paper attempts to review the potential of ocean renewable energy as an alternative source supplying renewable energies to Malaysia. It aims to promote ocean renewable energy to the public, industrial stakeholders and local authorities. It is an important source of renewable energy and industrial opportunity for a sustainable future.

\section{The status and prospects of renewable energy in Malaysia}

Malaysia is an oil and gas producing country covering an area of 330,000 square kilometers with a humid tropical climate. The country consists of thirteen states and three federal territories. The total population reached 28.3 million in year 2011, where the majority of the population lives in Peninsular Malaysia. The economy in Malaysia experienced a strong resumption in 2010 to achieve a Gross Domestic Product (GDP) growth rate of $7.2 \%$ after the global economy downturn in 2009 according to Central Bank of Malaysia [22]. The economy may able to grow continuously at a moderate pace in the subsequent years based on the prediction of Central Bank of Malaysia. 


\subsection{Energy supply}

Malaysia generated a total electricity power of 107,115 GWh to satisfy the demand of 93,713 GWh in 2009 [23]. The supply was able to meet the demand in 2005-2011. The supply and demand of electricity increased annually at an approximate rate of $3 \%$ according to recorded data as shown in Figure 1. By 2030, the predicted demand of Malaysia may be more than 150,000 GWh (1.5 times of the demand in 2010) due to the population growth [23].

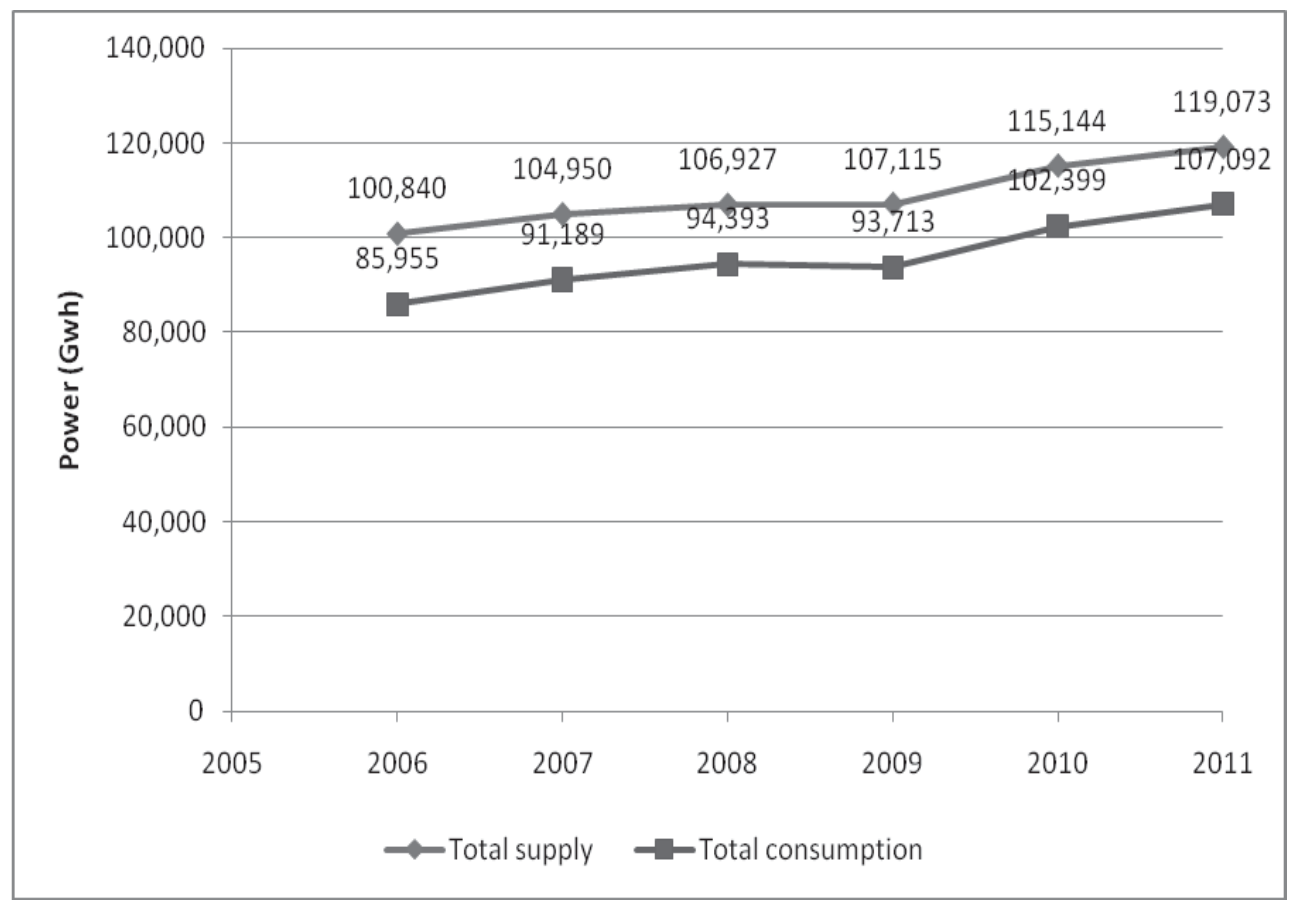

Figure 1: Total supply and consumption of electricity for the years 2006-2011

The electricity generated by using the gas turbines through gas-fired combined cycle plants is the major source of electricity power in Malaysia and followed by the steam stations according to the latest industrial report as shown in Figure 2 [24]. These sources could be economic in term of operational costs at the present time. The use of fossil fuel may release greenhouse gasses (GHG) 
to cause the environmental effects. These gases enhance the greenhouse effect and contribute to the global warming. A clean energy source is required to protect the environment. However, the efforts to harvest the renewable energy sources are still at the preliminary stage. It has only 53 Mega Watts from the renewable sources being connected to the national grid in between 2001 and 2009 [17].

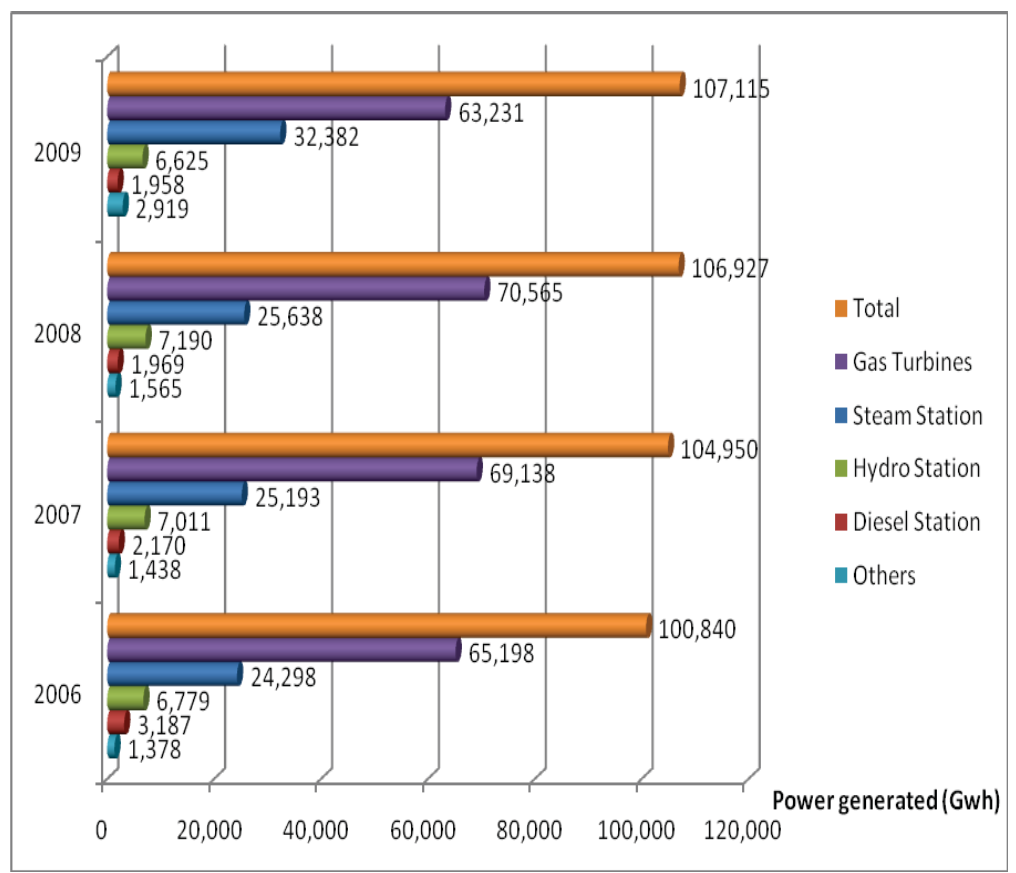

Figure 2: Types of sources in power generation for the years 2006-2009

Besides, 2,623 tons of pollutants were emitted to the Malaysian atmosphere in 2010 [25]. The air pollutants included ozone $\left(\mathrm{O}_{3}\right)$, carbon monoxide $(\mathrm{CO})$, nitrogen dioxide $\left(\mathrm{NO}_{2}\right)$, sulfur dioxide $\left(\mathrm{SO}_{2}\right)$ and particulate matter (PM10). These air pollutants were mainly generated by the mobile sources (1830 tons), power plants (619 tons) industrial activities (114 tons), and others (61 tons) as illustrated in Figure 3. The mobile sources or the modes of transportation were contributed the major share of pollutant emissions and showed a faster growth rate than other sectors [26]. 


\subsection{Energy policy}

Malaysia has considered using and developing some sources of renewable energy for electricity generation years ago. Many policies and programs were implemented to promote the renewable energies [20]. For instance, the government had focused on tax exemption and allowance [27, 28]. In addition, legislations have been introduced recently to construct a structured policy for long term in harvesting renewable energy. National Renewable Policy and Action Plan was launched by the Ministry of Energy, Green Technology and Water in 2009. This plan aims to enhance the utilisation of renewable energy in contributing towards the national electricity supply security and sustainable socio-economic development. Meanwhile, the future developments and prospects of renewable energy have been planned to focus on the various sources including biogas, biomass, solar power and mini-hydro [17]. 
The plan provides a practical direction for future electricity generation based on the available resources and the forecasted development [29]. In addition, the Government (parliament) has passed two Acts simultaneously regarding renewable energy and published in the Gazette on $2^{\text {nd }}$ June of 2011. Gazette is the official portal of Malaysian government for the publication of all federal legislation. The new enacted laws are the Renewable Energy Act 2011, and Sustainable Energy Development Authority Act 2011 (SEDA 2011).

The Renewable Energy Act 2011 focuses on only four sources of renewable energy in electricity generation, namely: biogas, biomass, small hydropower and solar photovoltaic. Malaysia has promoted and developed these four sources since 1990s [30, 31, 32, 33]. This is also not including the recent development on wind energy as highlighted in Pulau Perhentian, Sabah and Sarawak [34, 35]. Therefore, one of main reasons in selecting these four sources in the Act is mainly due to their levels of implementation and maturity in the industry. The main purpose of the Act is to establish and implement a special tariff system in order to catalyze the generation of renewable energy and related administrative matters. This Act needs to be read in conjunction with the regulations and rules set out by the Ministry of Energy, Green Technology and Water, which has been conferred with the powers to regulate the new tariff system.

The new tariff system or Feed-in Tariff (FiT) obliges the main power distribution companies to buy from the approved Feed-in holders (electricity producers) their electricity generated from renewable sources under a fixed FiT rate for a specified period of 16 or 21 years. 
Two types of FiT system can be enjoyed by the electricity producer. The first is the basic FiT rates for the installed capacity and the second is different categories of FiT rates based on the total production in Mega Watts. Meanwhile, the producers are able to receive a bonus FiT rate on top of the basic FiT rate if the producers have fulfilled certain requirements as stated in the Renewable Energy (Feed-In Approval and Feed-In Tariff Rate) Rules 2011. The criteria for bonus FiT rates was aimed for the sources from biogas, biomass, and solar photovoltaic, such as:

- Biogas: (a) extra RM 0.02 (per KWh) for the use of gas engine technology with electrical efficiency of above 40\%; (b) extra RM 0.01 for the use of locally manufactured or assembled gas engine technology; and (c) extra RM 0.08 for the use landfill or sewage gas as fuel source.

- Biomass: (a) extra RM 0.02 for the use of gasification technology; (b) extra RM 0.01 for the use of steam-based electricity generating systems with overall efficiency of above 14\%; and (c) extra RM 0.01 for the use of locally manufactured or assembled gasification technology; (d) extra RM 0.1 for the use of municipal solid waste as fuel source.

- Solar photovoltaic: (a) extra RM 0.26 for the use in an installation in buildings or building structures; (b) extra RM 0.25 for the use as building material; (c) extra RM 0.03 for the use of locally manufactured or assembled solar photovoltaic modules; and (d) extra RM 0.01 for the use of locally manufactured or assembled solar inverters. 
The entitlement of the bonus FiT rates is subjected to the submission of the necessary documentation. A person or an organization (or other recognized body) that fails to disclose, or provides false information or documents to the Sustainable Energy Development Authority, could be liable to a fine, or imprisonment after conviction. The fine will not exceed three hundred thousand ringgit, or imprisonment for a term not exceeding three years, or both. Therefore, the above-mentioned Authority has been granted powers and functions for all matters related to the renewable energy under the recent SEDA 2011.

Eventually, the FiT would encourage the use of renewable energy and bring a significant reduction of carbon dioxide $\left(\mathrm{CO}_{2}\right)$. Besides, the new policy creates career opportunities for interested parties of both individuals and organisations to obtain a secured return in long term under the protection of law. Meanwhile, it would also encourage extensive research and development activities for the renewable energy.

\subsection{The need for ocean renewable energies}

According to the largest bibliographic database, Scopus, the terms "ocean energy" or "marine energy" were searched under the keywords, abstract and article title. These keywords were selected to examine the growth and need for ocean renewable energies around the globe. Figure 4 illustrates the rapid growth of this research area in the past ten years from 2002 until 2011. 


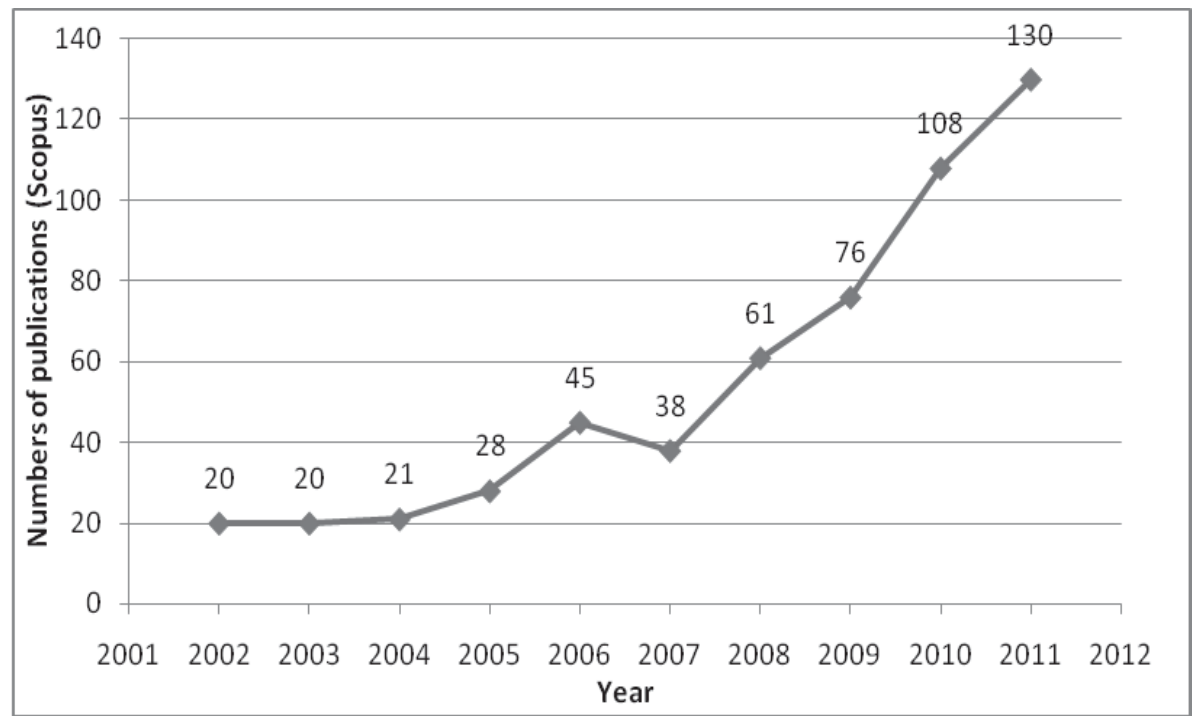

Figure 4: The growth of interest in ocean energy or marine energy based on publications for the years 2002-2011

\section{Ocean renewable energies}

Ocean energy can be categorised as tidal barrage, tidal current energy, wave energy, ocean thermal energy conversion (OTEC) power, and salinity gradient power [26], as illustrated in Figure 5. Tidal turbine is widely accepted as a cost effective method to harness ocean energy compared with wave energy, OTEC power, and salinity gradient power [36]. Tidal barrages are less environmental friendly compared to the other four methods earlier such as the projected construction of the Severn Barrage in Wales, United Kingdom. 


\subsection{Tidal barrage}

Tidal barrages consist of a large, dam-like structure built across the mouth of a bay, or estuary in an area with a large tidal range as illustrated in Figure 6. It applies the principles of hydroelectric generation from the tidal current flows in both directions using turbines, sluice gates, embankments and ship locks [37]. As the level of the water changes with the tides, a difference in height develops across the barrage. Water is allowed to flow through the barrage via the turbines, which can provide power during the ebb tide (receding), flood tide (allowing water to fill the reservoir via sluice gates during flood tide), or during both tides. This generation cycle means that, depending on the site, power can be delivered twice, or four times per day on a 
highly predictable basis. Two examples of famous tidal barrages include the La Rance barrage in France and Incheon barrage in Korea.

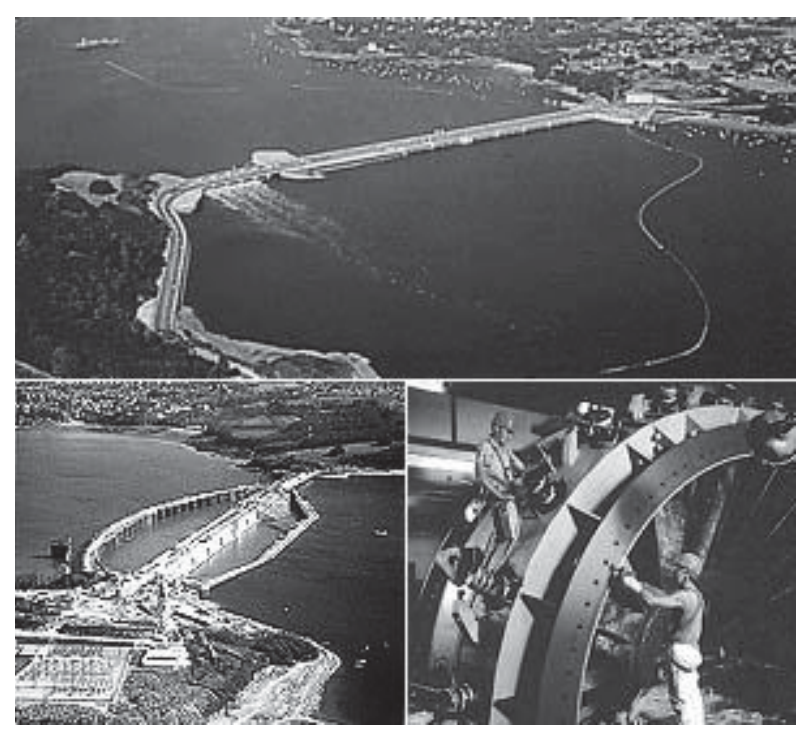

Figure 6: Tidal barrage in estuary, La Rance, France [38]

Tides are created by the gravitational attraction of the moon and the sun acting on the oceans of the rotating earth, the relative motions causing the surface of the oceans to be raised and lowered periodically [39]. Tidal power can be extracted by impounding a tide with a barrage to recover potential energy, or alternatively by extracting kinetic energy directly from the tidal stream. A vertical-axis turbine (Darrieus turbine) has a potential advantage over a horizontal turbine in that it is able to extract power form any direction without adjustment. Nevertheless, the sluice gate or conveyance is of significant importance for power generation efficiency up to $15 \%$ [40, 41].

Malaysia has used hydropower to generate electricity for decades. The main hydropower plants in Malaysia are: the Kenyir Sultan Mahmud Power Station with 400MW installed capacity, the Pergau Hydroelectric Power Station with 600MW installed capacity, and the Temenggor Hydroelectric Power Plant with 348MW installed capacity. Hydropower consists of 11\% of the 
total installed electricity capacity of 17,326MW (August 2004) for the Peninsular of Malaysia [42]. However, Malaysia has no tidal barrage installation, even though hydropower is widely applied in Malaysia.

\subsection{Tidal current energy}

Malaysia has a long coastline with great potential to develop electricity generation from ocean energy. Tidal turbines can be categorised as either vertical-axis, or horizontal-axis turbines [26] (see Figure 7). The vertical-axis turbine is able to capture the energy from various directions without adjusting the position of turbine, whereas the horizontal-axis turbine may be able to capture more tidal energy. Ocean energy is new to Malaysia compared with the coal or gas-fired power plants.
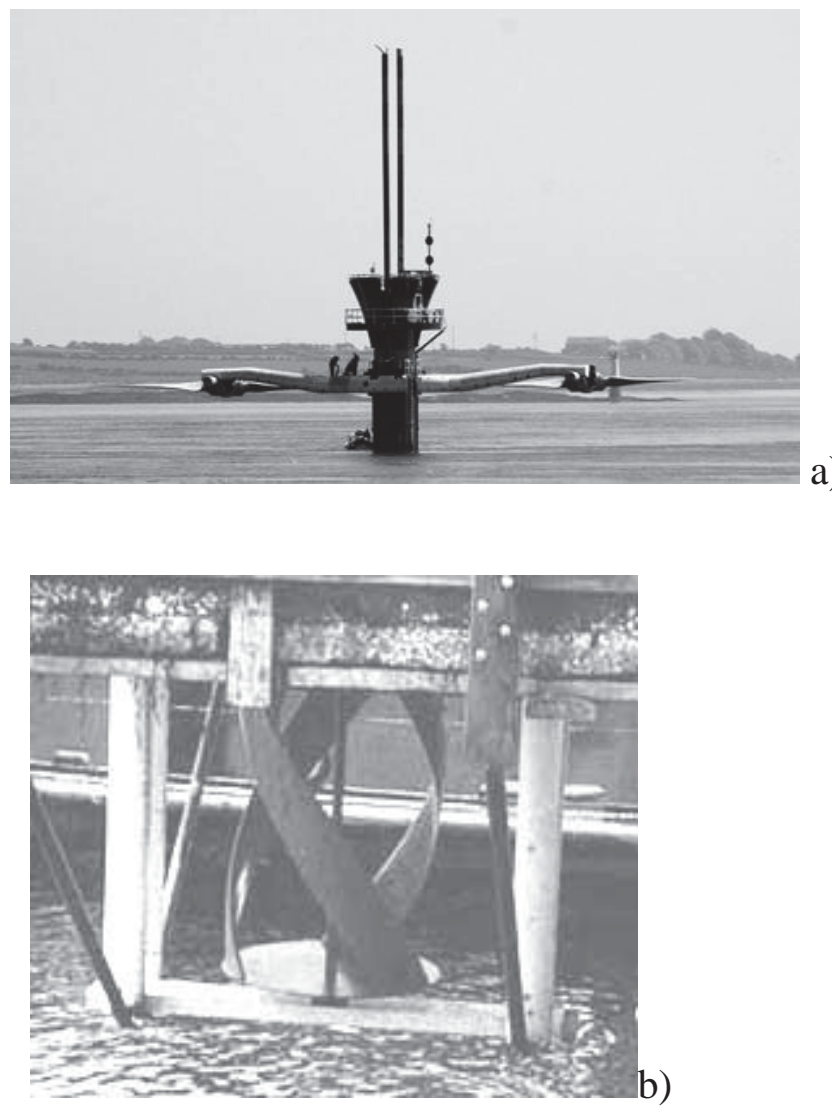
Figure 7: Tidal turbine: a) Horizontal-axis tidal turbine (Source: Marine Current Turbines, Ltd.);

b) Vertical-axis tidal turbine [43]

The original concept of the Darrieus turbine was patented in the USA in 1931 under the name of G. J. M. Darrieus [44]. Modification of the Darrieus turbine to enable the extraction of energy from tidal streams rather than wind has attracted a number of international researchers. In 1996, Kiho et al., [45] tested a physical Darrieus-type marine current turbine of $1.6 \mathrm{~m}$ diameter at Kurushima Strait, and concluded that the highest efficiency attainable in a tidal flow of over 1.1 $\mathrm{m} / \mathrm{s}$ was $56 \%$, at a tip speed ratio (TSR) of 2:1. The generation by tidal currents are proven to be effective and influenced greatly by the tidal turbine arrays [46, 47, 48].

Malaysia is a marine country and has a long coastline with great potential to harness tidal current energy. The tidal current development is still in the research stage with efforts from the National Oceanography Directory (NOD) to push forward the implementation of tidal energy with the collaboration of the Oceanography Intergovernmental Committee (OIC), UNESCO Bangkok. Universities play an important role in tidal current research. The University of Malaya has an interest in a tidal stream energy application in the Straits of Malacca. The University Technology of Malaysia, University Terengganu of Malaysia, National University of Malaysia, University of Sarawak and Universiti Tunku Abdul Rahman have started research activities in this area.

\subsection{Wave energy}

Oscillating Water Column (OWC) may be an economic method to harness wave energy in Malaysia compared with other wave devices as illustrated in Figure 8. The wave energy in the 
Straits of Malacca and South China Sea may possibly be harnessed using OWC devices. Air turbines are used almost exclusively by the OWC type wave energy devices for converting fluid power into rotary-mechanical power [49].

The basic form of an OWC is a mostly closed chamber that is open to the sea at the bottom and open to the air via one or more air turbines. The most popular design is known as the Wells Turbine, and involves symmetrically shaped airfoils mounted at $90^{\circ}$ to the airflow. However, other turbine designs could be applied as well such as variable-pitch turbine blades. Although the flywheel motion of the turbine does provide some energy storage, the overall output of an air turbine is generally highly variable [49] depending on the designs. A significant amount of power will probably be required in order to connect the OWC to the grid. Thus, the investigations of the OWC wave energy are an important step in harnessing the wave energy in Malaysia.

Wave energy may not be suitable or commercially viable as tidal current energy in Malaysia. Wave energy conversion technology requires an average annual wave power density greater than $50 \mathrm{~kW} / \mathrm{m}^{2}$. However, the wave power density of Malaysia's ocean is less than $50 \mathrm{~kW} / \mathrm{m}^{2}$. Hence, Malaysia's ocean has rather low potential in harnessing wave energy [50]. Furthermore, the shoreline changes due to wave energy have caused erosion and sedimentation issues [51]. 


\subsection{Ocean Thermal Energy Conversion (OTEC)}

Ocean thermal energy conversion (OTEC) makes use of the temperature difference between the warm surface of the ocean and the colder layers underneath as illustrated in Figure 9. The amount of energy due to solar heating available in the temperature gradient between the hot and cold seawater can be substantially larger than the energy required to pump the cold seawater up from the lower layers of the ocean. The warm water from the surface is used to boil a working fluid (the seawater itself under low pressure in open cycle systems). The working fluid then runs through a turbine and being condensed using the cold seawater pumped from the depths. OTEC is best suited to areas near the equator, where the intense solar radiation warms the surface significantly [52]. 


\title{
3.5. Salinity gradient power
}

Salinity gradient power makes use of the potential energy available when saltwater and

Figure 9: Ocean Thermal Energy Conversion (OTEC)

Malaysia has a good potential in harnessing ocean thermal energy from the Sabah Trough. The water depth at the Sabah Tough is $2900 \mathrm{~m}$ and the temperature is about $3{ }^{\circ} \mathrm{C}$ at the bottom compared with $29{ }^{\circ} \mathrm{C}$ at the surface. This temperature difference makes OTEC possible for use in Malaysia because according to the scientific literature, an area with a $22{ }^{\circ} \mathrm{C}$ temperature difference has the potential to generate renewable energy [53]. Recent developments in OTEC show that ammonia is a good choice for the organic Rankine cycle utilized in OTEC, from which a greater output could be generated [54].

\begin{abstract}
freshwater mix. The pressure induced by the movement of water across a membrane can be used to run turbines via a process known as "Pressure-Retarded Osmosis." This process is illustrated below in Figure 10. The latest research development of this energy system uses reverse
\end{abstract}


electrodialysis ion-exchange membrane stacks in microbial reverse-electrodialysis cells, to capture salinity-gradient energy from ammonium bicarbonate salt solutions, which is able to produce greater energy as well as greater recovery of the energy [55].

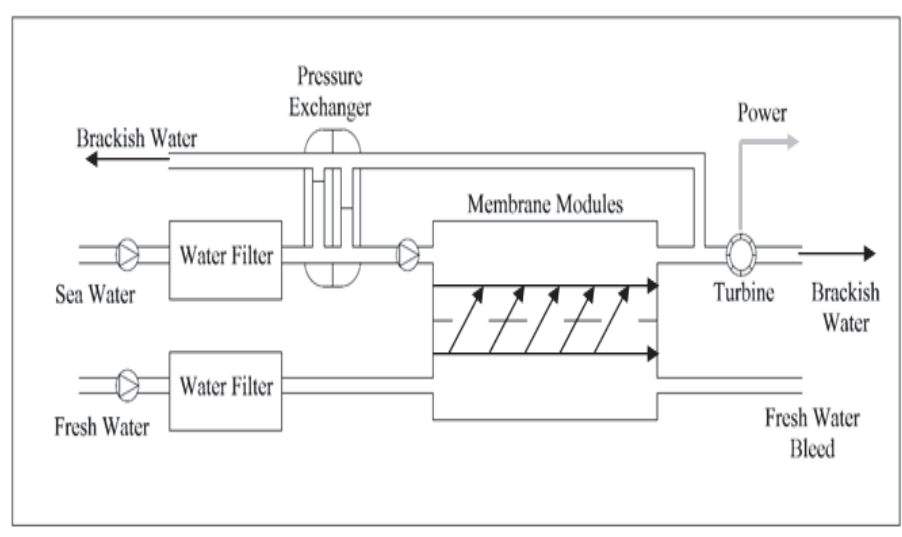

Figure 10: Salinity gradient power

Malaysia has a high rainfall rate. In February 2012, the total rainfalls were between 175\% and $485 \%$ above average in the northern area, and between $66 \%$ and $122 \%$ above the monthly average on the west coast of the Peninsula Malaysia [56]. The average rainfall throughout the whole country is approximately $250 \mathrm{~cm}$ per year [57]. The main rivers in the west of the Peninsular of Malaysia, such as: Sungai Perak (390 km), Sungai Selangor (80 km), and Sungai Muar (190 km) are drained into the Straits of Malacca (main river) [58]. Exchange of organic matter and mineral nutrients occur in the estuary area and hence, a salinity gradient is generated [59].

\section{Challenges and comparison}


Electricity demand is projected to increase steadily worldwide, particularly for Asian countries [16]. Therefore, Asian countries are expected to put more efforts into generating electricity from renewable sources. Malaysia has committed to promote the renewable energy but ocean energies have been ignored or are not being emphasised in the current policy. Therefore, seven key challenges facing the feasibility studies have been investigated for ocean renewable energies in Malaysia [60]. These factors are as follows:

i. Predictability: the development of ocean energy requires proper design and planning with regard to the required electricity generation.

ii. Manufacturability: after the design and planning, a prototype needs be manufactured with consideration for the future mass development.

iii. Installability: availability of sites for the installation is crucial with regard to marine traffic and environmental considerations.

iv. Operability: when the operation takes place, it should consider the cost for control and maintenance along the period of electricity generation.

v. Survivability: the system/method must be able endure extreme conditions due to the possibility of extreme weather or natural disasters.

vi. Reliability: the output of electricity generation is consistent and operated to a planned schedule during its life-span.

vii. Affordability: the project life-cycle cost (initial cost, operation cost and maintenance cost) must be balanced so as to provide a return on investment within a reasonable period. 
Subsequently, Table 1 shows the comparison between the ocean energies and their suitability for application in Malaysia. The comparison was referred to an overview status of the energies, and also considerations of policy making and environmental issues. This approach was merely to assess and render a generic view on the overall development of the energies, instead of detailed examinations on each and every one of the energy. Nevertheless, the potential rating could be fine-tuned, or even changed from time to time due to the quick pace of development and research activities on these ocean renewable energies.

Table 1: Comparison of the potential among the ocean renewable energies

\begin{tabular}{|c|c|c|c|c|c|c|c|c|}
\hline & Predictability & Manufacturability & Installability & Operability & Survivability & Reliability & Affordability & References \\
\hline $\begin{array}{l}\text { Tidal } \\
\text { barrage }\end{array}$ & $\mathrm{H}$ & $\overline{\mathrm{M}}$ & $\bar{M}$ & $\bar{M}$ & $\bar{M}$ & $\overline{\mathrm{H}}$ & $\mathrm{L}$ & $\begin{array}{l}{[10,37,38,} \\
40,41,61- \\
64]\end{array}$ \\
\hline $\begin{array}{l}\text { Tidal } \\
\text { turbine }\end{array}$ & $\mathrm{H}$ & $\mathrm{H}$ & $\mathrm{H}$ & $\mathrm{H}$ & M & $\mathrm{H}$ & M & $\begin{array}{l}{[9-10,45-} \\
47,61,65- \\
68,73]\end{array}$ \\
\hline $\begin{array}{l}\text { Wave } \\
\text { energy }\end{array}$ & $\mathrm{M}$ & M & $\mathrm{H}$ & M & M & M & M & $\begin{array}{l}{[49-51,62,} \\
69,70]\end{array}$ \\
\hline $\begin{array}{l}\text { OTEC } \\
\text { power }\end{array}$ & $\mathrm{L}$ & $\mathrm{L}$ & M & M & M & $\mathrm{L}$ & M & $\begin{array}{l}{[52-54,62,} \\
70]\end{array}$ \\
\hline $\begin{array}{l}\text { Salinity } \\
\text { gradient } \\
\text { power }\end{array}$ & M & L & M & M & M & $\mathrm{L}$ & M & {$[55-57,71]$} \\
\hline
\end{tabular}

Note: Potentiality for the classification of high (H), medium (M), and low (L). 
Tidal turbine has a relatively high potential in extracting the tidal current energy in terms of the cost, environmental impact and overall reliability [72]. Moreover, optimisation and maximising of the power output has been well assessed and formulated at the current stage of development, such as the numbers of turbines should be installed, a practical way in estimating the power extraction and so on [66, 68, 73], even though extracting the energy under difficult situation, such as lower current speed [67]. This would increase and strengthen the confidence level of the interested parties who are going to extract ocean renewable energy using tidal turbine.

Besides, tidal energy is a promising energy source available for the electricity generation in Malaysia [20]. The analytical study suggested the tidal energy extraction in a few locations of Malaysia is able to reach an annual electricity generation of 14.5 GWh [50]. This prediction serves as a good foundation for further research and development into tidal energy. Overall, the potentiality of tidal turbine is relatively high as shown in Table 2.

Table 2: Summary of potentiality

\begin{tabular}{ll}
\hline Sources of ocean renewable energy & Summary of potentiality \\
\hline Tidal barrage & Medium \\
Tidal turbine & High \\
Wave energy & Medium/high \\
OTEC power & Low/Medium \\
Salinity gradient power & Low/Medium
\end{tabular}




\section{The potential of the Straits of Malacca}

Malaysia has a high coast per area ratio of 14; the coastline is $4675 \mathrm{~km}$ long and the land area is $328550 \mathrm{~km}^{2}$ [74]. The Straits of Malacca is one of the longest straits in the world, which has a constant minimum flow of $0.5 \mathrm{~m} / \mathrm{s}$ with maximum up to $4 \mathrm{~m} / \mathrm{s}$ in particular regions [75]. It is an important shipping waterway in terms of economics and strategic location connecting the Indian and the Pacific Oceans [76]. The average depth around the areas of the Straits is approximately $40 \mathrm{~m}$ with an average current speed of $2 \mathrm{~m} / \mathrm{s}$ or equivalent to 4 knots, which is sufficient to make the turbine works. Figure 11 illustrates the location of the Straits of Malacca. The preliminary study mentioned earlier focused on the locations at Pulau Jambongan, Kota Belud, and Sibu [50].

Marine Renewable Energy research group at University of Malaysia (MRE@UM) by Lam proposed the potential site selection in the Straits of Malacca in the recent publication [77]. The Acoustic Doppler Current Profiler (ADCP) data at a coordinate of (41130, 37.1300N, 1001320, 09.0200E) showed the maximum velocity is $0.48 \mathrm{~m} / \mathrm{s}$ on 7 March 2011, which the device was installed at the seabed with $8 \mathrm{~m}$ depth. The station was located at a safe place rather than where with known current by Malaysian Meteorological Department. The flow speed is expected to be higher according to the communication with local community and a more detailed site measurement is on planning. 


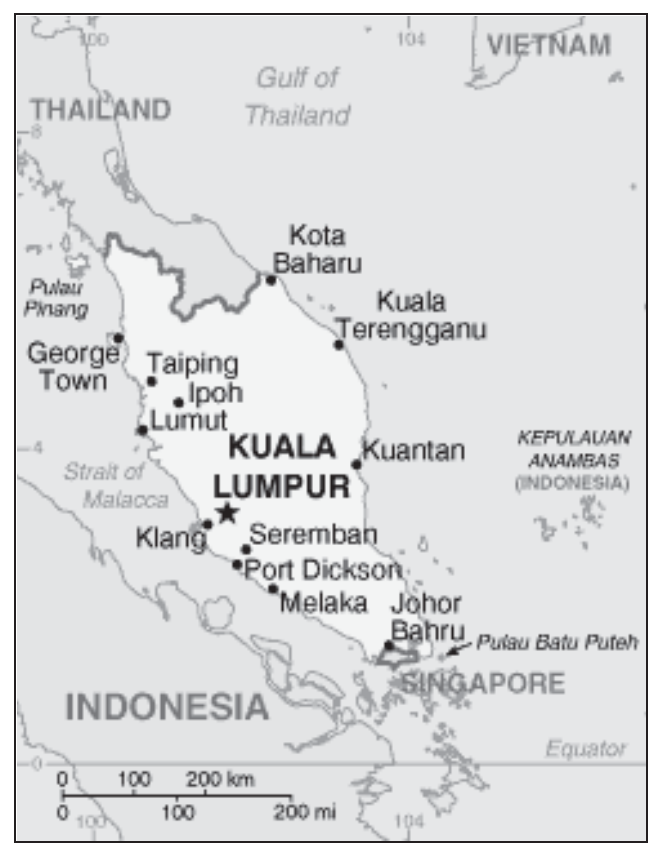

Figure 11: Location of the Straits of Malacca

Therefore, the potential of the Straits of Malacca is rather high for harvesting ocean energies, and this supply the electricity to the capital city of Malaysia, namely, Kuala Lumpur. This is because the distance is relatively short from the coast to the metropolitan area of Kuala Lumpur or the Klang Valley. Furthermore, the nature of the Straits, that are approximately 500 miles long, has great potential pertaining to the seven key challenges and feasibility studies as explained earlier, especially for the method of tidal turbine. The selection of this type of ocean energy is based on the current literature and also Malaysia's environmental considerations and policies. Even though ocean energy is not listed as one of the sources of renewable energy under the new Acts, the Sustainable Energy Development Authority that has been granted power under SEDA 2011, could make changes and amendments to the Act when tidal energy has been proven practical for harvesting ocean energy in Malaysia. Therefore, this review is able to highlight and promote 
public awareness and inspire the Authority to dedicate more efforts into ocean renewable energies.

\section{Discussion and conclusion}

Malaysia has committed to invest in and use renewable energy since 1990s. The Renewable Energy Act 2011 and SEDA 2011 have been enacted, where FiT is implemented to provide incentives for electricity producers using renewable energy. However, biogas, biomass, solar power and mini-hydro are the only sources that have been considered for the incentives provided under the current energy policy. There is a need to review and amend the energy policy due to non-inclusion of ocean renewable energy. This is because a review of the literature and related findings has clearly indicated a high potentiality of marine energy to electricity generation. The increased interest in ocean renewable energies becomes apparent in recent years. This area of research has shown rapid growth during the past ten years, based on the results from Scopus. If the search was conducted using the specific terms of the five types of ocean energy, it would generate a result with a tremendous number of publications. Overall, the continued development of the ocean energies is a global trend.

Additionally, tidal turbine has a great potential compared with other types of ocean energy. Furthermore, Malaysia has an added advantage with its strategic location for harvesting the tidal energy from the long coastline in the Straits of Malacca. The generation of electricity from a tidal energy source would be a cost effective method to combat the effects of climate change [36]. 
Nevertheless, the environmental effects from ocean renewable energy sources need to be examined, especially on tidal turbines. The effects usually occur at the local level (sea water) with regard to environmental consequences and also unexpected low output of electricity being generated from the ocean [12]. Subsequently, the marine mammals or wildlife and water quality might also be affected. However, the effects on these marine mammals remain unknown [78]. The effects on water quality caused by tidal energy systems have yet to be confirmed, but these effects are probably varied between the estuaries and coastlines [79]. Although the environmental effects are thought to be minor, the effects are unclear at this juncture . The proper planning and investigations are required in the preliminary stages, particularly regarding the aspects of construction and maintenance of tidal turbines. Research also needs to be undertaken to determine whether sufficient output of electricity could be generated by a tidal energy system or not before commencing mass development along the coastline.

The review renders an important insight into the potentiality of ocean renewable energies in Malaysia. It is recommended that local government takes serious consideration and places confidence in the development of ocean renewable energy in Malaysia, by amending the current Acts to provide incentives for electricity producers to use this source of renewable energy. Meanwhile, the industrial stakeholders from both public and private sectors should allocate more funds or investments for venturing into the development of ocean renewable energies particularly tidal energy in the Straits of Malacca. Ultimately, the success of this sustainability paradigm requires a joint effort and a shared responsibility from all parties. 


\section{Acknowledgments}

The authors wish to extend their gratitude to the Ministry of Higher Education for the financial support under the UM/MOHE High Impact Research Grant (H-1600-00-D000047) and to also thank Mr. Wenxi Zhu from IOC-UNESCO and Prof. Dr. Nor Aieni binti Hj Mokhtar from the National Oceanography Directorate (NOD), for their discussions.

\section{References}

[1] Schubert SF, Turnovsky, SJ. The impact of oil prices on an oil-importing developing economy. Journal of Development Economics 2011;94 (1):18-29.

[2] Ziolkowska JR, Ziolkowska, B. Product generational dematerialization indicator: A case of crude oil in the global economy. Energy 2011;36(10):5925-5934.

[3] Gómez-Loscos A, Montañés A, Gadea MD. The impact of oil shocks on the Spanish economy. Energy Economics 2011;33(6):1070-1081.

[4] Ali Ahmed HJ, Wadud IKMM. Role of oil price shocks on macroeconomic activities: An SVAR approach to the Malaysian economy and monetary responses. Energy Policy 2011;39(12):8062-8069.

[5] Archanskaïa E, Creel J, Hubert P. The nature of oil shocks and the global economy. Energy Policy 2012;42:509-520.

[6] Hanabusa K. The effect of 107th OPEC Ordinary Meeting on oil prices and economic performances in Japan. Renewable and Sustainable Energy Reviews 2012;16(3):16661672. 
[7] Rahman S, Serletis A. Oil price uncertainty and the Canadian economy: Evidence from a VARMA, GARCH-in-Mean, asymmetric BEKK model. Energy Economics 2012;34(2):603-610.

[8] Zevenhoven R, Beyene A. The relative contribution of waste heat from power plants to global warming. Energy 2011;36(6):3754-3762.

[9] Harris D. Monitoring global warming. Energy and Environment 2011;22(7):929-937.

[10] Peters GP, Aamaas BT, Lund M, Solli C, Fuglestvedt JS. Alternative "global warming" metrics in life cycle assessment: A case study with existing transportation data. Environmental Science and Technology 2011;45(20):8633-8641.

[11] Armstrong PJ, Green KC, Soon W. Research on forecasting for the manmade global warming alarm. Energy and Environment 2011;22(8):1091-1104.

[12] Moriarty P, Honnery D. What is the global potential for renewable energy? Renewable and Sustainable Energy Reviews 2012;16:244-252.

[13] May W. Assessing the strength of regional changes in near-surface climate associated with a global warming of $2{ }^{\circ} \mathrm{C}$. Climatic Change 2012;110 (3-4):619-644.

[14] Erdinc O, Uzunoglu M. Optimum design of hybrid renewable energy systems: Overview of different approaches. Renewable and Sustainable Energy Reviews 2012;16 (3):14121425.

[15] International Energy Agency (IEA). Key World Energy Statistics. Paris: OECD/IEA 2011.

[16] International Energy Agency (IEA). World Energy Outlook. Paris: OECD/IEA 2009.

[17] Ministry of Energy, Green Technology and Water, Malaysia. National Renewable Energy Policy \& Action Plan. Kuala Lumpur: KeTTHA 2009. 
[18] Ong HC, Mahlia TMI, Masjuki HH. A review on energy scenario and sustainable energy in Malaysia. Renewable and Sustainable Energy Reviews 2011;15:639-647.

[19] Oh TH, Pang SY, Chua SC. Energy policy and alternative energy in Malaysia: Issues and challenges for sustainable growth. Renewable and Sustainable Energy Reviews 2010;14:1241-1252.

[20] Hashim H, Ho WS. Renewable energy policies and initiatives for a sustainable energy future in Malaysia. Renewable and Sustainable Energy Reviews 2011;15:4780-4787.

[21] Shafie SM, Mahlia TMI, Masjuki HH, Andriyana A. Current energy usage and sustainable energy in Malaysia: A review. Renewable and Sustainable Energy Reviews 2011;15:43704377.

[22] Central Bank of Malaysia. Bank Negara Malaysia Annual Report 2010. Available at: http://www.bnm.gov.my/files/publication/ar/en/2010/ar2010_book.pdf [accessed 10.03.2012].

[23] Department of Statistics, Malaysia. Mining, Manufacturing and Electricity. Available at: http://www.statistics.gov.my/portal/download_Buletin_Bulanan/download.php?file=BPB M/2012/JAN/08_Mining.pdf [accessed 11.03.2012].

[24] Department of Statistics, Malaysia. Electricity. Available at: http://www.statistics.gov.my/portal/download_Economics/download.php?file=DATA_SE RIES/2011/pdf/16Elektrik.pdf [accessed 11.03.2012].

[25] Department of Statistics, Malaysia. Environment. Available at: http://www.statistics.gov.my/portal/download_Economics/download.php?file=DATA_SE RIES/2011/pdf/19Alam_Sekitar.pdf [accessed 11.03.2012]. 
[26] Powertech Labs (2009), Ocean energy: global development Status, IEA-OES Document No.: T0104.

[27] Poh KM, Kong HW. Renewable energy in Malaysia: a policy analysis. Energy for Sustainable Development 2002;6(3):31-39.

[28] Jaafar MZ, Kheng WH, Kamaruddin N. Greener energy solutions for a sustainable future: issues and challenges for Malaysia. Energy Policy 2003;31(11):1061-1072.

[29] Shamsuddin AH. Development of Renewable Energy in Malaysia-Strategic Initiatives for Carbon Reduction in the Power Generation Sector. Procedia Engineering 2012;49:384-391.

[30] Dalimin MN. Renewable energy update: Malaysia. Renewable Energy 1995;6(4):435-439.

[31] Sulaiman F, Zain A.N. Current status of energy utilization and future of renewable energy in Malaysia. Renewable Energy 1996;9:1148-1151.

[32] Kannan KS. Strategies for promotion and development of renewable energy in Malaysia. Renewable Energy 1999;16:1231-1236.

[33] Ahmad S, Kadir MZAA, Shafie S. Current perspective of the renewable energy development in Malaysia. Renewable and Sustainable Energy Reviews 2011;15(2):897904.

[34] Shafie SM, Mahlia TMI, Masjuki HH, Andriyana A. Current energy usage and sustainable energy in Malaysia: A review. Renewable and Sustainable Energy Reviews 2011;15(9):4370-4377.

[35] Ong HC, Mahlia TMI, Masjuki HH. A review on energy scenario and sustainable energy in Malaysia. Renewable and Sustainable Energy Reviews 2011;15(1):639-647.

[36] Dai YM, Lam W-H. Numerical study of straight-bladed Darrieus-type tidal turbine. Proceedings of the Institution of Civil Engineers, Energy 2009;162:67-76. 
[37] Etemadi A, Emami Y, AsefAfshar O, Emdadi A. Electricity generation by the tidal barrages. Energy Procedia 2010;12:928-935.

[38] Green Thoughts. Marine Renewable Energy. Vol 6, (2007). Available at: http://greenthoughts.us/ree/marine/ [accessed 11.02.2012].

[39] Johansson TB, Kelly H, Reddy AKN, William RH, Burnham J. Renewable Energy: Sources for Fuels and Electricity, Washington: Island Press 1993.

[40] Xia J, Falconer RA, Lin B, Tan G. Estimation of annual energy output from a tidal barrage using two different methods. Applied Energy 2012;93:327-336.

[41] Yoon KS, Ryu Y, Bae DW, Kim HJ. Two- and three-dimensional hydraulic model tests of sluice-conveyance for a tidal power plant design. Journal of Coastal Research 2011;64:636-640.

[42] Othman ZA. The Future of Hydropower in Malaysia. Jurutera 2005;May:32-33.

[43] Gorlov A. Helical Turbine Assembly Operable Under Multidirectional Gas and Water Flow for Power and Propulsion Systems [US Patent No. 6,036,443] (2000).

[44] Paraschivoiu I. Wind Turbine Design: With Emphasis on Darrieus Concept. Montreal: Presses Internationales Polytechnique 2002.

[45] Kiho S, Shiono M, Suzuki K. The power generation from tidal currents by Darrieus turbine. Renewable Energy 1996;9:1242-1245.

[46] Ahmadian R, Falconer RA. Assessment of array shape of tidal stream turbines on hydroenvironmental impacts and power output. Renewable Energy 2012;44:318-327.

[47] Turnock SR, Phillips AB, Banks J, Lee RN. Modelling tidal current turbine wakes using a coupled RANS-BEMT approach as a tool for analysing power capture of arrays of turbines. Ocean Engineering 2011;38:1300-1307. 
[48] Gato LMC, Curran R. The Energy Conversion Performance of Several Types of Wells Turbines Designs. Proc. Institutions of Mechanical Engineers, Part A, Journal of Power Engineering 1997;211:133-145.

[49] EPRI. (2007), Indian Wave Energy, pp. 3-5. Available at: http://www.niot.res.in/m1/mm1.html [accessed 21.02.2012].

[50] Lim YS, Koh SL. Analytical assessments on the potential of harnessing tidal currents for electricity generation in Malaysia. Renewable Energy 2010;35:1024-1032.

[51] Marghany M, Hashim M, Cracknell A. Simulation of shoreline change using AIRSAR and POLSAR C-band data. Environmental Earth Sciences 2011;64(4):1177-1189.

[52] Vega LA. Ocean Thermal Energy Conversion (OTEC) (1999) 1-6, 11. Available at: http://www.otecnews.org [accessed 19.01.2012].

[53] Abu BJ. Ocean Thermal Energy., from The prospects of Generating Renewable Energy till Eternity: Not Nuclear, but from the Thermal-energy Differential of the Water Depth off Sabah Trough. Available at: http://straightfront.blogspot.com/2009/03/ocean-thermalenergy.html [accessed 11.04.2012].

[54] Sun F, Ikegami Y, Jia B, Arima H. Optimization design and exergy analysis of organic rankine cycle in ocean thermal energy conversion. Applied Ocean Research 2012;35:3846.

[55] Cusick RD, Kim Y, Logan BE. Energy capture from thermolytic solutions in microbial reverse- electrodialysis cells. Science 2012;335(6075):1474-1477.

[56] MOSTI. Malaysian Meteorological Department: Monthly Weather Bulletin. Available at: http://www.met.gov.my/index.php?option=com_content\&task=view\&id=846\&Itemid=158 $\underline{6}$ [accessed 31.03.2012]. 
[57] Saw S-H. The population of Peninsular Malaysia. Singapore: Institute of Southeast Asian Studies 2007.

[58] WWF. (2003). WWF: Our Water Sources. Availble at:

http://www.wwf.org.my/media_and_information/learning_sharing/freshwater_main/ [accessed 10.04.2012].

[59] Ong J, Gong W, Wong C, Zubir HD. Characterization of a Malaysian Mangrove Estuary. Estuaries 1991;14(1):38-48.

[60] Markus M, Robin W. Enabling science and technology for marine renewable energy. Energy Policy 2008;36:4376-4382.

[61] Rourke FO, Boyle F, Reynolds A. Marine current energy devices: Current status and possible future applications in Ireland. Renewable and Sustainable Energy Reviews 2010;14(3):1026-1036.

[62] Malik AQ. Assessment of the potential of renewables for Brunei Darussalam. Renewable and Sustainable Energy Reviews 2011;15:427-437.

[63] Darmawi, Sipahutar R, Bernas R, Imanuddin, M. Renewable energy and hydropower utilization tendency worldwide. Renewable and Sustainable Energy Reviews 2013:17:213215.

[64] Trapani K, Millar DL, Smith HCM. Novel offshore application of photovoltaics in comparison to conventional marine renewable energy technologies. Renewable Energy 2013;50:879-888.

[65] Rourke FO, Boyle F, Reynolds A. Renewable energy resources and technologies applicable to Ireland. Renewable and Sustainable Energy Reviews 2009;13:1975-1984. 
[66] Estimating the power potential of tidal currents and the impact of power extraction on flow speeds Ross Vennell Renewable Energy 36 (2011) 3558e3565

[67] Hassan HF, El-Shafie A, Karim OA. Tidal current turbines glance at the past and look into future prospects in Malaysia. Renewable and Sustainable Energy Reviews 2012;16:57075717

[68] Walters RA, Tarbotton MR, Hiles CE. Estimation of tidal power potential. Renewable Energy 2013;51:255-262.

[69] Bahaj AS. Generating electricity from the oceans. Renewable and Sustainable Energy Reviews 2011;15:3399- 3416.

[70] Hammar L, Ehnberg J, Mavume A, Cuamba BC, Molander S. Renewable ocean energy in the Western Indian Ocean. Renewable and Sustainable Energy Reviews 2012;16(7):49384950.

[71] Zabihian F, Fung AS. Review of marine renewable energies: Case study of Iran. Renewable and Sustainable Energy Reviews 2011;15:2461-2474.

[72] Chen W-B, Liu W-C, Hsu M-H. Modeling assessment of tidal current energy at Kinmen Island, Taiwan. Renewable Energy 2013;50:1073-1082.

[73] Vennell R. Realizing the potential of tidal currents and the efficiency of turbine farms in a channel. Renewable Energy 2012;47:95-102.

[74] CIA Fact Book. Coast Area Ratio arranged by Wikipedia. Available at: http://en.wikipedia.org/wiki/List_of_countries_by_length_of_coastline\#cite_note1[accessed 11.03.2012]. 
[75] American University of Washington DC, The Impact of Transportation on Wildlife in the Malacca Straits. Available at: http://www1.american.edu/ted/malacca.htm [accessed 11.03.2012].

[76] Qu X, Meng Q. The economic importance of the Straits of Malacca and Singapore: An extreme-scenario analysis. Transportation Research. Part E 2012; 48:258-265.

[77] Sakmani AS, Lam WH, Hashim R, Chong HY. Site selection for tidal turbine installation in the Strait of Malacca. Renewable and Sustainable Energy Reviews 2013. (In press)

[78] Boehlert GW, Gill AG. Environmental and ecological effects of ocean renewable energy development: a current synthesis. Oceanography 2010; 23(2):68-81.

[79] Kadir M, Ahmadian R, Evans BB, Rauen W, Falconer R. A review of the potential water quality impacts of tidal renewable energy systems. Renewable and Sustainable Energy Reviews 2012; 16:329-341. 